\title{
Climate Conditions on the Tibetan Plateau During the Last Glacial Maximum and Implications for the Survival of Paleolithic Foragers
}

\author{
Xiangjun Liu ${ }^{1 *}$, Lu Cong ${ }^{2}$, Xiangzhong $L^{3}{ }^{3}$, David Madsen ${ }^{2 *}$, Yixuan Wang ${ }^{2}$, Yonggang Liu ${ }^{4}$ \\ and Jun Peng ${ }^{5}$ \\ ${ }^{1}$ College of Geography and Environmental Science, Northwest Normal University, Lanzhou, China, ${ }^{2}$ Qinghai Salt Lake Institute, \\ Chinese Academy of Sciences, Xining, China, ${ }^{3}$ Yunnan Key Laboratory of Earth System Science, Yunnan University, Kunming, \\ China, ${ }^{4}$ Department of Atmospheric and Oceanic Sciences, Peking University, Beijing, China, ${ }^{5}$ School of Resource and \\ Environment and Safety Engineering, Hunan University of Science and Technology, Xiangtan, China
}

OPEN ACCESS

Edited by:

Guanghui Dong,

Lanzhou University, China

Reviewed by:

Mingrui Qiang,

South China Normal University, China

Shugang Kang,

Institute of Earth Environment

(CAS), China

*Correspondence: Xiangjun Liu

xiangjunliu@126.com,

David Madsen

dbmadsen@charter.net

Specialty section:

This article was submitted to Quaternary Science, Geomorphology and Paleoenvironment, a section of the journal

Frontiers in Earth Science

Received: 14 September 2020

Accepted: 23 October 2020

Published: 26 November 2020

Citation:

LiuX, Cong L, LiX, Madsen D, Wang Y,

Liu Y and Peng J (2020) Climate

Conditions on the Tibetan Plateau During the Last Glacial Maximum and Implications for the Survival of Paleolithic Foragers.

Front. Earth Sci. 8:606051. doi: 10.3389/feart.2020.606051
Environmental conditions on the Tibetan Plateau (TP) during the last glacial maximum (LGM) are poorly known. Existing studies of environmental proxies and climate model simulations are contradictory, with interpretations varying between cold-dry and cold-wet environmental conditions which differentially influenced lake volumes, loess deposition and vegetation communities across the TP. Genetic and archaeological studies suggest anatomically modern paleolithic foragers initially occupied the TP between 60 and $30 \mathrm{ka}$, and may have seasonally occupied the TP during the LGM. Hence, a better understanding for LGM environmental conditions is needed in order to estimate whether paleolithic foragers could have survived on the TP during the extreme LGM cold stage. Here we report the investigation of lacustrine sediments and beach deposits within two paleoshorelines around Dagze Co on the southern TP, 22 and $\sim 42 \mathrm{~m}$ higher than the present lake level. Optical age estimates suggest the sediments were deposited during the LGM and mid-Holocene, respectively. TraCE-21 climate model simulation results suggest that net annual LGM precipitation in the Dagze Co basin was lower than the mid-Holocene, but about the same as that of the past 1,000 years. Combining the optical age estimates with TraCE-21 and CAM4 climate model simulation results, we deduce that increased summer precipitation and glacier meltwater supply, combined with decreased lake surface evaporation, produced LGM lake levels $\sim 22 \mathrm{~m}$ higher than present. We also synthesized paleoenvironmental records reported across the TP spanning the LGM. This synthesis suggests that the LGM climate in the northern TP was cold and dry, but that some of the southern TP was cold and wet. These relatively wetter LGM conditions in the southern TP may have favored the growth of cold-resistant plants which, in turn, may have supported larger herbivore populations, and provided food for paleolithic foragers. We conclude that seasonal or short-term human occupation of the TP during the LGM was thus more likely in the southern TP than in the north.

Keywords: tibetan plateau, last glacial maximum, high lake levels, climatic conditions, paleolithic foragers 


\section{INTRODUCTION}

A recent study of a human mandible fossil found in Xiahe County, in the northeastern TP, indicates that Denisovans occupied the TP before $160 \mathrm{ka}$ (during the penultimate glacial period), much earlier than contemporary Tibetans who arrived in the region much later (Chen et al., 2019; Zhang et al., 2020). Both genetic research (Lu et al., 2016) and archaeological investigations (Zhang et al., 2018a; Zhang et al., 2018b) suggest that anatomically modern human foragers conquered high elevations and at least seasonally colonized the Tibetan Plateau (TP) between 60 and $30 \mathrm{ka}$. Genetic research indicates there was some genetic continuity between initial Paleolithic people on the TP and modern Tibetans, with the former contributing $\sim 6 \%$ of the present Tibetan gene pool (Zhao et al., 2009; Lu et al., 2016). Research has further suggested that Paleolithic people successfully overcame the TP's harsh climate during the last glacial maximum period (LGM, between $\sim 26$ and $\sim 19 \mathrm{ka}$ (Clark et al., 2009)) and made a genetic contribution (albeit limited) to contemporary inhabitants (Zhao et al., 2009). This is supported by archaeological evidence from the southern TP, including human handprints and footprints on hot spring travertine at Quesang and a fireplace remnant dated to within the LGM (Zhang and Li, 2002). At the Nwya Devu site stone artifacts within alluvial sands and gravels were mainly deposited from 40-30 ka, but extending to the LGM (Zhang et al., 2018b). However, optical dating and $\mathrm{U}$-series dating of the travertine at the Quesang site is controversial (Meyer et al., 2017; Zhang and Li, 2017). Zhang et al. (2017) suggest that low temperatures, hypoxia and low bioproductivity would have impeded yearround hunter-gatherer occupation of the high TP until the development of agriculture after $\sim 5.2 \mathrm{ka}$, moreover, Dong et al. (2020) contend that hunter-gatherer groups in China may have adapted to climate change by mobility and subsistence strategy adjustments before 10,000 BP. At present, it appears that Paleolithic foragers first colonized the TP sometime before $30 \mathrm{ka}$. However, whether they stayed on the TP and adapted to the extremely cold LGM climate or needed to move down to surrounding low elevation regions during the LGM before reoccupying the TP again after the last deglacial (Madsen et al., 2006) is still unknown.

It is difficult to address these alternatives since environmental conditions on the TP during the LGM remain poorly known. Over the course of the past 30 years, extensive investigations of TP paleoenvironmental changes have been conducted by scientists within China and from abroad. However, most are focused on the last deglaciation and Holocene stages, with only a few records spanning the LGM (An et al., 2012; Liu et al., 2019; Chen et al., 2020 and references there in). Ice cores older than the Holocene are scarce on the TP, with only the Guliya ice cap records extending through the LGM (Thompson et al., 1997). Loess is widely distributed across the TP, but has only been continuously accumulated since the last deglacial (e.g., Lai et al., 2009; Qiang et al., 2013; Stauch, 2015; Qiang et al., 2016; Liu et al., 2017). There are more than one thousand lakes scattered across the TP, and lacustrine sediments are the most widely studied proxy records used to reconstruct paleoenvironmental changes.
However, the majority of these studies only cover the last deglacial and Holocene periods (Chen et al., 2020 and the references there in). Existing paleoenviornmental records indicate that lakes on the TP shrank during the LGM, with some large lakes becoming almost completely desiccated (Madsen et al., 2008; An et al., 2012; Yan and Wünnemann, 2014; Jin et al., 2015; Liu et al., 2015; Zhu et al., 2015). Loess was eroded by strong westerly winds and the advancement of glaciers during the LGM (Liu et al., 2017; E et al., 2018). Ice wedge casts indicative of permafrost developed widely across the northern TP, and vegetational communities were substantially degraded (Pan and Chen, 1997; Liu and Lai, 2013). All these paleoenvironmental records suggest that the climate of the TP became very cold and dry during LGM. However, a global atmospheric general circulation model (GCM) and a regional climate model with detailed land surface process simulation results (RegCM2) suggest that TP climates were likely cold and wet during the LGM, mainly due to a decrease in evaporation and an increase of water vapor inflow through its south boundary (Yu et al., 2003). This would have resulted in an increase in runoff over the TP caused mainly by a decrease in evapotranspiration (Yu et al., 2003; Zheng et al., 2007). Recently, Li and Morrill (2013) compiled lake level information of monsoonal and arid Central Asia regions and compared them with Paleoclimate Modeling Intercomparison Project Phase 2 (PMIP2) simulated lake level variations during the LGM. They found that some parts of the southern and western TP had LGM lake levels higher than today, while the levels of eastern and northern TP lakes declined substantially. Kuhle (1998) reconstructed the glacial equilibrium line altitude (ELA) during the LGM, concluding the ELA was $1,200-1,500 \mathrm{~m}$ lower than today and proposed a $1,000-2,700 \mathrm{~m}$ thick ice sheet covered the whole Tibetan Plateau during the LGM. However, this interpretation has been widely disputed (Shi, 2004; Lai et al., 2009; Yan et al., 2018). In summary, controversies still exist about the climatic and environmental conditions on the TP during the LGM, in particular whether or not climatic conditions on the TP differed spatially. More research is needed to resolve these questions.

Closed-basin lakes in the TP are natural water reservoirs and are sensitive to hydrological changes. Understanding lake level fluctuations and the driving forces which cause them, can thus help clarify past hydrological changes in the TP. At a global scale, lake level variations between glacial and interglacial periods are primarily controlled by thermodynamics and dynamic changes deriving from large scale cooling or warming, land-sea and meridional temperature gradients, sea level, and ice sheet topography (McGee, 2020). Shoreline deposits and lacustrine sediments are often used to track past lake level variations in closed-basin lakes. Paleoshorelines can provide much clearer evidence of former lake size changes than can core records (Quade and Broecker, 2009) because lake surface areas and depths can be directly measured. These proxy variables adjust rapidly to prevailing hydrological changes and reflect shifts in the water budget for the lake basins as determined by the changing relationship between precipitation and evapotranspiration (McGee, 2020). A closed-basin lake receives water from river inflow, direct precipitation, and groundwater, and loses water 
primarily through evaporation since there are no river outlets. Lake highstands can occur when one of the following relationships are met:

(1) $\mathrm{W}_{\text {in }}$ increase, $\mathrm{E}_{\mathrm{L}}$ increase, and $\Delta \mathrm{W}_{\text {in }}>\Delta \mathrm{E}_{\mathrm{L}}$;

(2) $\mathrm{W}_{\text {in }}$ increase, $\mathrm{E}_{\mathrm{L}}$ no change or $\mathrm{E}_{\mathrm{L}}$ decrease;

(3) $\mathrm{W}_{\text {in }}$ no change or $\mathrm{W}_{\text {in }}$ decrease, $\mathrm{E}_{\mathrm{L}}$ decrease, and $\Delta \mathrm{W}_{\text {in }}<\Delta \mathrm{E}_{\mathrm{L}}$;

Where $\mathrm{W}_{\text {in }}$ is the sum of water input to the lake (including river runoff, precipitation, and groundwater); $\mathrm{E}_{\mathrm{L}}$ is water evaporation from the lake surface; $\Delta \mathrm{W}_{\text {in }}$ and $\Delta \mathrm{E}_{\mathrm{L}}$ are changes in $W_{\text {in }}$ and $E_{L}$ between beginning and ending time points. It is important to note that lake level fluctuations are not simply responses to precipitation changes, but are associated with basinwide water budget changes.

Many lakes in the TP are ringed by conspicuous paleoshorelines, suggesting they were much larger in the past. These paleoshorelines were rarely studied before about 2 decades ago because they often lack organic materials for radiocarbon dating. As other dating methods, such as optically stimulated luminescence dating (OSL), U-series dating and cosmogenic nuclide exposure dating, have become increasingly reliable, the number of well-studied and well-dated lake shoreline sequences has increased dramatically. Here, we add to this body of data by reporting the investigation of Dagze Co in the south-central TP. We mapped and sampled paleoshorelines at the southern margin of the Dagze Co, and dated two paleoshorelines using OSL dating in order to determine when the highest paleoshorelines were formed and what the nature of lake surface fluctuations was during the last glacial and especially during the LGM.

The TP covers a wide range of latitudes from $25^{\circ} \mathrm{N}$ to $40^{\circ} \mathrm{N}$. A number of studies of atmospheric water hydrogen and oxygen isotopes (Tian et al., 2001; Yao et al., 2013) suggest the TP can be divided into a westerly influenced northern part and an Indian summer monsoon (ISM) controlled southern part, with the two divided approximately at $33^{\circ} \mathrm{N}$ latitude. Here we divide the TP into these two sub-regions at $33^{\circ} \mathrm{N}$ latitude in order to compare shoreline histories of lakes in the two regions and investigate if they were influenced by different atmospheric circulations patterns and had different climate features during the late Quaternary.

\section{SAMPLE COLLECTION AND METHODS}

\section{Dagze Co Location and Environmental Parameters}

Dagze Co $\left(31.82^{\circ}-31.98^{\circ} \mathrm{N}, 87.36^{\circ}-87.65^{\circ} \mathrm{E}\right.$, with a modern lake surface elevation of $4,480 \mathrm{~m}$ above sea level [asl], Figure 1) is now a brackish lake with a salinity of $19.1 \mathrm{~g} / \mathrm{L}$. The main anions are $\mathrm{CO}_{3}{ }^{2-}, \mathrm{SO}_{4}{ }^{2-}$ and $\mathrm{Cl}^{-}$, and the main cations are $\mathrm{Na}^{+}$and $\mathrm{K}^{+}$ (Supplementary Table S1). The modern lake area and maximum lake depth are $\sim 299 \mathrm{~km}^{2}$ and $\sim 38 \mathrm{~m}$ (Hou et al., 2017), respectively. The basin catchment area is $12845 \mathrm{~km}^{2}$ (Hou et al., 2017). Present inflow is mainly from the Bogcarg Zangbo River. The mean annual precipitation is $\sim 316 \mathrm{~mm}$, and the mean annual temperature is $\sim 0.55^{\circ} \mathrm{C}$ in this region (Hou et al., 2017). About 15 paleoshorelines are well-preserved on the eastern and southern lake margin and can be identified on Google-Earth images and in the field (Figure 2A). These shorelines indicate dramatic past water budget changes. We investigated these paleoshorelines during the summers of 2017 and 2018, and collected OSL dating samples from sand and siltrich portions of cleaned profiles. Here we focus on the highest paleoshoreline (S15) and on another medium height paleoshoreline [S10] (Figures 1, 2A). The surveyed elevation of the highest paleoshoreline is $4,521.6 \mathrm{~m}$ asl, consistent with a previous report that the highest paleoshoreline is $4,522 \mathrm{~m}$ asl (Qiao et al., 2010).

\section{Sample Collection}

Profile $17-10\left(87.5628^{\circ} \mathrm{E}, 31.8119^{\circ} \mathrm{N}\right)$ is located on paleoshoreline $\mathrm{S} 10$, about $22.4 \mathrm{~m}$ above the modern lake level (ALL) (Figure 2). This shoreline is spectacular and can be easily identified in the field. However, it lacks beach gravels in the upper part of the profile (Figures 2C, 3), and we speculate surface morphological features of this shoreline may have been formed by wave action during the Holocene lake recessive phase. A thin layer of gravel pavement covers the surface of the shoreline, overlying interbedded fine sand, silt, and coarse sand layers that extend downward to $1.1 \mathrm{~m}$ depth (Figure 3). These fine sand, silt, and coarse sand layers all have ripple laminations or sub-horizontal bedding suggesting they are near shore lacustrine sediments deposited when lake levels were several meters above this section according to the empirical relationships between water depths and sediments obtained from Qinghai Lake (Liu et al., 2018). Fine sand layers alternate with varied thickness of red silt layers with no obvious bedding below $1.1 \mathrm{~m}$ (Figure 3; Supplementary Figure S1,2). Although the red silt layers may be of alluvial or fluvial origins, they were well sorted and look different from alluvial deposits that are composed of poorly sorted mixtures of gravels, sands and silts (Supplementary Figure S3). This suggests they were reworked by lake water sometimes after they were deposited, and that their OSL ages are related to the reworking processes. Two beach gravel layers are located at the lower part of the section. The upper beach gravel layer is $20 \mathrm{~cm}$ thick $(2.0-2.2 \mathrm{~m})$ and the lower beach gravel layer is only $\sim 5 \mathrm{~cm}$ thick $(2.70-2.75 \mathrm{~m})$ (Figure 3$)$. The beach gravels are $3-5 \mathrm{~cm}$ in diameter, well sorted, moderately rounded, and no bedding can be observed (Figure 3; Supplementary Material S2). These gravel layers did not contain enough sand-sized sediments for OSL age estimates and could not be dated. OSL dating samples 17-10-1, 17-10-2, 17-10-3, 17-10-4, 17-10-5 and 17-10-6 were collected from sand lenses or sand rich layers at depths of 2.55, 1.95, 1.6, 1.3. 0.9, and $0.6 \mathrm{~m}$ (Figures 2C, 3), respectively. Another exposed section containing lacustrine sediments was found at approximately the same elevation of section $17-10$ but $\sim 10 \mathrm{~km}$ to the east (Supplementary Figure S3). It is $\sim 1.7 \mathrm{~m}$ high and its sedimentary structures correlate well with the upper part of section 17-10. The upper $0.45 \mathrm{~m}$ consist of alluvial deposits composed of gravels, sands and silts. These are underlain by light greyish nearshore lacustrine fine sands extending downward to an unknown depth (Supplementary Figure S3). We therefore 


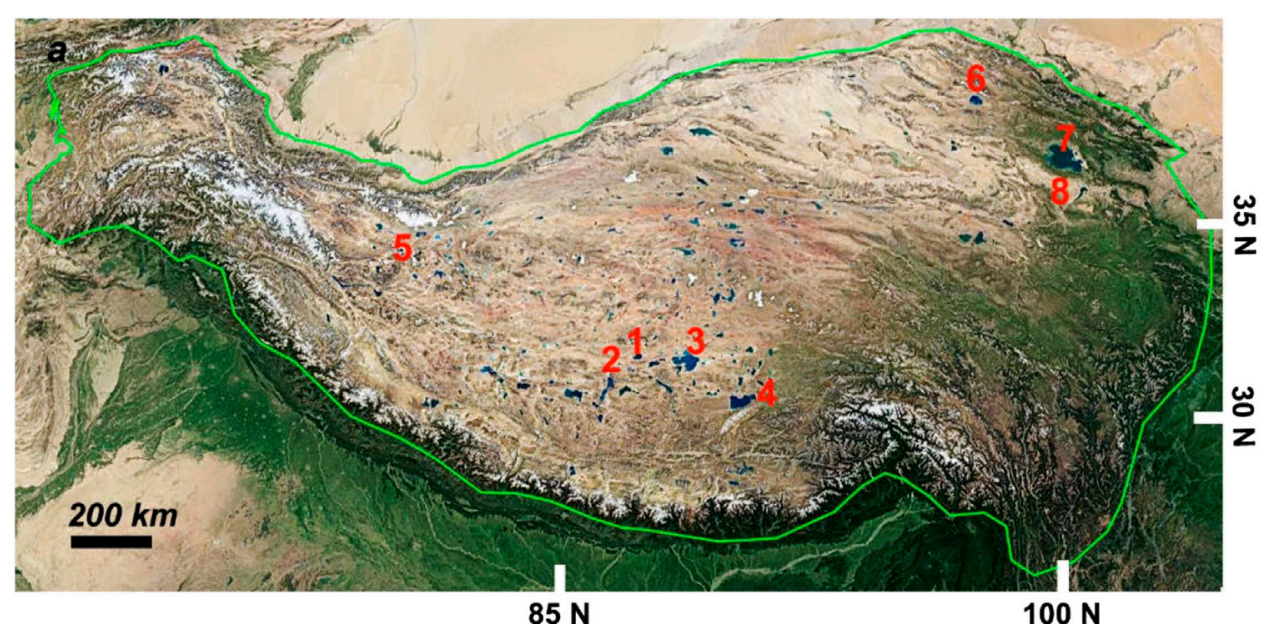

\section{$\underset{\boldsymbol{\omega}}{\boldsymbol{\omega}}$}

$85 \mathrm{~N}$

$100 \mathrm{~N}$

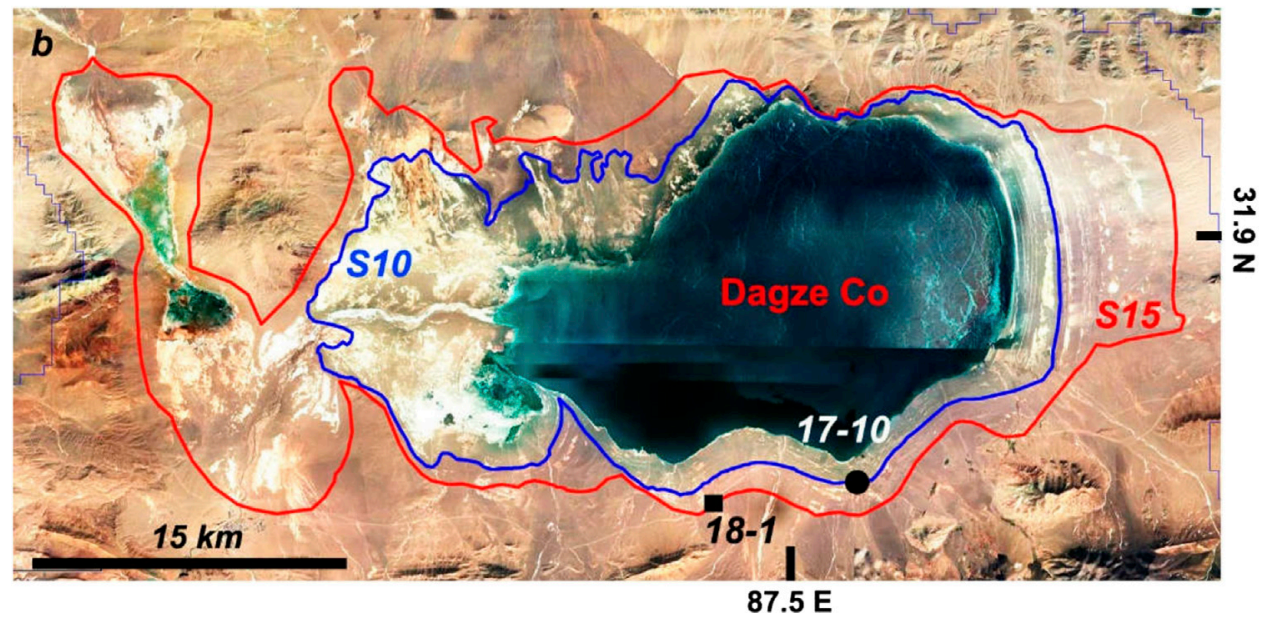

FIGURE 1 | (A) Location of Dagze Co and other lakes mentioned in the text; Dagze Co-1, Dangqiong Co-2, Seling Co-3, Nam Co-4, Longmu Co-5, Hala Lake-6, Qinghai Lake-7, Dalianhai Lake-8. The green-line is the outline of the TP. (B) Enlargement showing Dagze Co. The blue and red lines are the outlines of the LGM and midHolocene lake margins, respectively. The black dot and square are the 17-10 and 18-1 sampling sites. S10 and S15 (the highest in the basin) are high stand paleoshorelines that are 22.4 and $41.6 \mathrm{~m}$ higher than present lake level, respectively. Satellite images are from Google-Earth.

think that these nearshore lacustrine sediments are related to the expansion of Dagze Co. and are not lagoon or alluvial deposits. The sedimentary features and sediment compositions of section 17-10 are quite similar to those in a spectacular paleoshoreline located at the southern margin of Longmu Co. That paleoshoreline is $\sim 4 \mathrm{~m}$ high and composed of lacustrine sands lacking beach gravels, and is thought to have formed during the Holocene lake regression period (Supplementary Figure S4; Liu et al., 2016).

Profile $18-1\left(87.4915^{\circ} \mathrm{E}, 31.8033^{\circ} \mathrm{N}\right)$ is on paleoshoreline S15, $\sim 41.6 \mathrm{~m}$ ALL. This shoreline is the highest visible paleoshoreline surrounding the lake and extends from the southern to eastern lake margin. The top $0.2 \mathrm{~m}$ of the profile consists mainly of aeolian deposits with scattered coarse sand and small gravel with no visible bedding (Figure 4). Beach gravels with oblique bedding and diameters ranging from 2 to $5 \mathrm{~cm}$ are deposited between 0.2 and $1.0 \mathrm{~m}$ depth. A layer of medium to coarse sand with subhorizontal bedding is $1.0-1.1 \mathrm{~m}$ below the surface (Figure 4). This sand layer is underlain by alluvial deposits composed of poorly sorted angular gravels, sands and silts extending to an unknown depth. OSL dating sample (18-1A) was taken from the beach gravels in an area where there is a large sand component, and another sample (18-1B) was collected from the middle of the sand layer $\sim 1.05 \mathrm{~m}$ below the surface (Figure 4).

\section{OSL Dating}

Samples were transported to the Luminescence Dating Laboratory of the Qinghai Salt Lake Institute, Chinese Academy of Sciences, and were pretreated under red safe light. Carbonates and organic materials were removed from the raw samples using $10 \% \mathrm{HCl}$ and $30 \% \mathrm{H}_{2} \mathrm{O}_{2}$, respectively. Medium and coarse sands were then separated through dry sieving and subjected to heavy liquid separation to obtain purer quartz. More detailed pre-processing information can be found in Liu et al. (2015).

The equivalent dose $\left(D_{e}\right)$ of purified quartz was determined using the single-aliquot regenerative-dose (SAR, Murray and Wintle, 2000). OSL measurements were carried out using an 


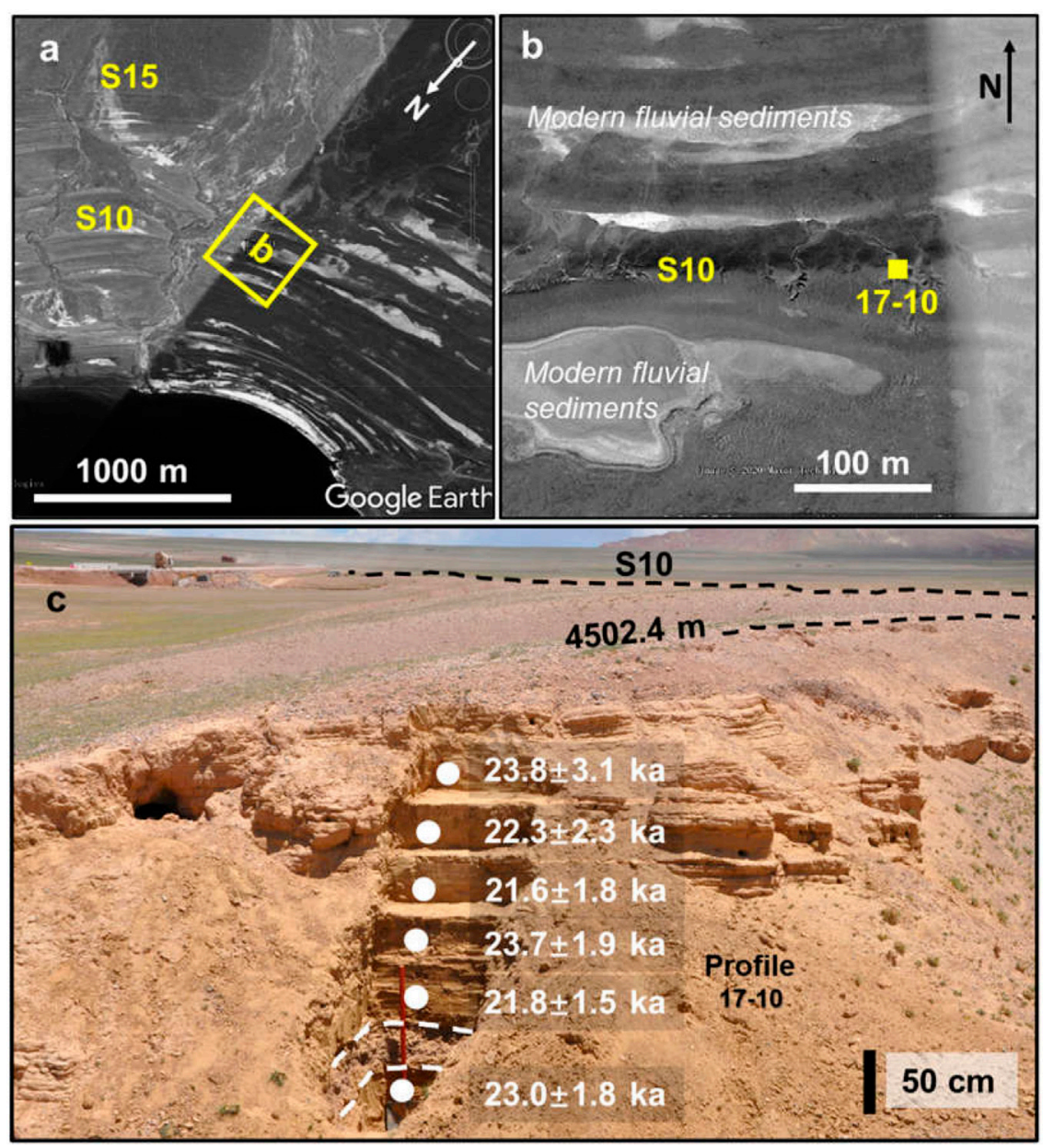

FIGURE 2 | (A) View of Dagze Co and the paleoshorelines located on the southern lake margin. (B) enlargement of the hollow square region outlined in yellow in (A), the yellow solid square represents the location of profile 17-10. (C) Profile 17-10 and associated OSL ages. The view is toward the east.

automated Risø TL/OSL DA-20 reader. The preheat and cutheat temperatures were determined by preheat plateau and dose recovery test experiments, set at $200^{\circ} \mathrm{C}$ and $160^{\circ} \mathrm{C}$ (Supplementary Figure S5), respectively. The $\mathrm{D}_{\mathrm{e}}$ was then measured by luminescence response. Natural luminescence $\left(\mathrm{L}_{\mathrm{n}}\right)$ was measured first, then numerous regenerative dose luminescences $\left(\mathrm{L}_{\mathrm{x}}\right)$ were measured sequentially, and corrected for sensitivity changes by the luminescence response $\left(\mathrm{T}_{\mathrm{x}}\right)$ to a constant test dose $\left(\mathrm{T}_{\mathrm{D}}\right)$ (Shi et al., 2017). The $\mathrm{L}_{\mathrm{x}} / \mathrm{T}_{\mathrm{x}}$ ratios were used to construct the regeneration dose growth curve, and the $\mathrm{L}_{\mathrm{n}}$ / $\mathrm{T}_{\mathrm{x}}$ ratio (natural luminescence to test dose response luminescence ratio) was projected onto the growth curve to calculate the $D_{e}$ (Figure S6, Murray and Wintle, 2000). Signals of the initial $0.64 \mathrm{~s}$ of stimulation were integrated for growth curve construction after subtraction of the last $10 \mathrm{~s}$ signals. Several samples show broad $\mathrm{D}_{\mathrm{e}}$ distributions and have large over-dispersion values (Figure S7), suggesting they may have been heterogeneously bleached before deposition. In order to diminish the influence of partial bleaching on age estimation, the single-aliquot age selection model for $\mathrm{D}_{\mathrm{e}}$ determination proposed by Arnold et al. (2007) was used to decide whether the 3-parameter minimum-age model (MAM-3) or the central-age model (CAM) was applied to calculate the $\mathrm{D}_{\mathrm{e}} \mathrm{s}$. R-language based luminescence data analysis package "numOSL" was used to select the suitable age model to calculate the $D_{e} s$ (Peng et al., 2013). Three out of 8 samples' $\mathrm{D}_{\mathrm{e}}$ were determined by using MAM-3, and the remaining $5 \mathrm{D}_{\mathrm{e}} \mathrm{s}$ were determined by using CAM (Table 1).

Concentrations of $\mathrm{U}$, Th and $\mathrm{K}$ were measured by the neutron activation analysis of dried and ground bulk samples (Supplementary Table S2). The radionuclide contents were converted to $\alpha$ and $\beta$ dose rates according to the conversion factors proposed by Guérin et al. (2011). The cosmic ray dose rate was determined as a function of sampling depth, altitude and geomagnetic latitude (Prescott and Hutton, 1994). The average water content for paleoshoreline sediments during the burial period may have varied which is hard to estimate. Some sampling positions were dry and some others were wet when we dug out fresh profiles. We therefore calculated ages using water contents of $10 \pm 5,15 \pm 5$ and $20 \pm 5 \%$ for each sample, and then selected ages of $10 \pm 5 \%$ water content for samples collected from relative 

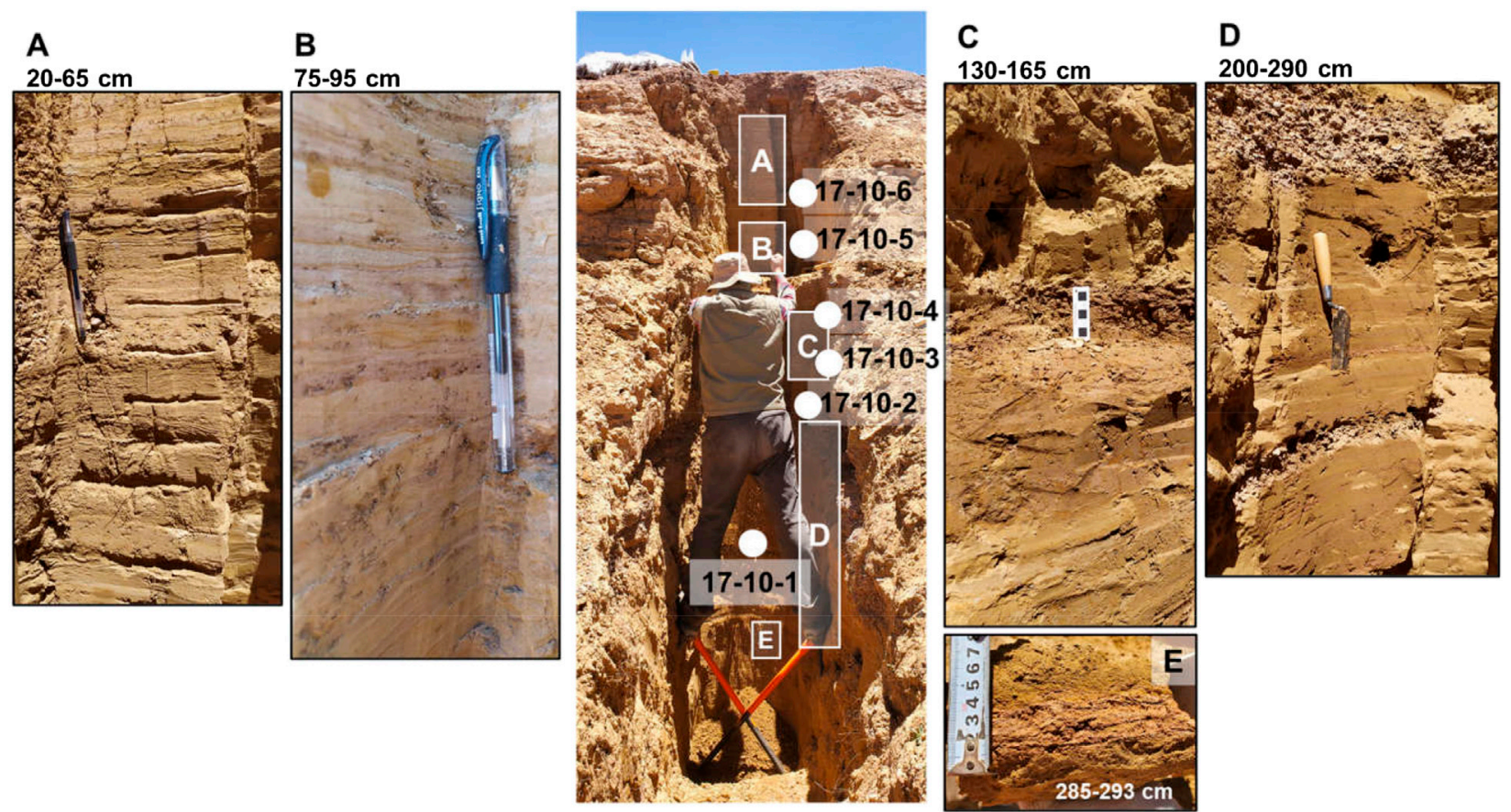

FIGURE 3 | Sedimentary structure details and composition of the 17-10 locality. The entire section is shown in the middle of the figure, with enlarged portions shown on the left and right sides.

dry strata and ages of $15 \pm 5 \%$ water content for samples collected from wet strata as their best approximate ages (Table 1).

\section{LGM Climate Simulations}

Glaciers over the western and southern TP expanded substantially during the LGM, with the total glacial coverage possibly reaching $70 \times 10^{4} \mathrm{~km}^{2}$ according to a $1 \mathrm{~km}$-resolution ice sheet model which assumes cooling of $6^{\circ} \mathrm{C}$ and a precipitation decrease of $50 \%$ over the TP (Yan et al., 2018). Recently, Liu et al. (2020) simulated the impact that glacier expansions over the western and southern TP had on Eurasian climate changes during the LGM using Community Atmosphere Model version 4 (CAM4). They discuss the influence of enlarged glaciers in the Himalayas and Pamir regions on local and regional temperature and precipitation changes during the LGM in contrast to areas where glaciers did not expand. Here, we use part of the simulation results of Liu et al. (2020) to investigate seasonal temperature and precipitation changes when glaciers expanded over the TP during the LGM.

The transient climate evolution of the last $22 \mathrm{ka}$ (referred to as TraCE-21) with the Community Climate System Model 3 (CCSM3) simulation results were used to calculate the annual and seasonal precipitation amounts, net annual precipitation amounts, annual and seasonal temperature changes for three time periods $(22-20,8-6,1-0 \mathrm{ka})$ over Qinghai Lake on the northeastern TP, Dagze Co on the southern TP and Longmu Co on the western TP. The TraCE-21 simulation is forced by realistic external forcing, including orbital insolation, greenhouse gases, ice sheets and freshwater fluxes (Liu et al., 2009). The model consists of four components (atmospheric-model, oceanicmodel, land-model and sea ice-model) coupled together (Yan et al., 2020). The spatial resolution of the TraCE-21 simulation is $3.75^{\circ} \times 3.75^{\circ}$ (Liu et al., 2009).

\section{RESULTS}

OSL dating results show that higher Dagze Co lake levels occurred at during the LGM and mid-Holocene (Table 1; Supplementary Figure S8). Nearshore lacustrine sediments at S10 (22.4 m ALL) were deposited between 23.8 and $21.6 \mathrm{ka}$ (Figure 2C; Supplementary Figure S8). The sedimentary structure features (coarse sands with ripple laminations in the upper part of profile 17-10 and two beach gravel layers in the lower part) suggest they were deposited when lake levels were fluctuating a few meters above or near paleoshoreline S10 during the LGM (Figure 3). The typical shoreline morphological features near the surface of S10 suggest they formed during the Holocene by waves which transformed older lacustrine sediments during a rapid regression of the lake. The speed of this regression resulted in only a few beach gravels being deposited at the surface at some locations or none at all at others. The lake area during the LGM highstand period was $\sim 530 \mathrm{~km}^{2}(\sim 1.8$ times the modern lake size). The high LGM lake level of Dagze Co, at an elevation of $\sim 4,500 \mathrm{~m}$ asl in the southern TP, confirms that an ice sheet covering the entire TP did not exist during the LGM.

The highest paleoshoreline (S15) is $41.6 \mathrm{~m}$ ALL. Two optical ages for samples collected from beach sediments and a sand layer 


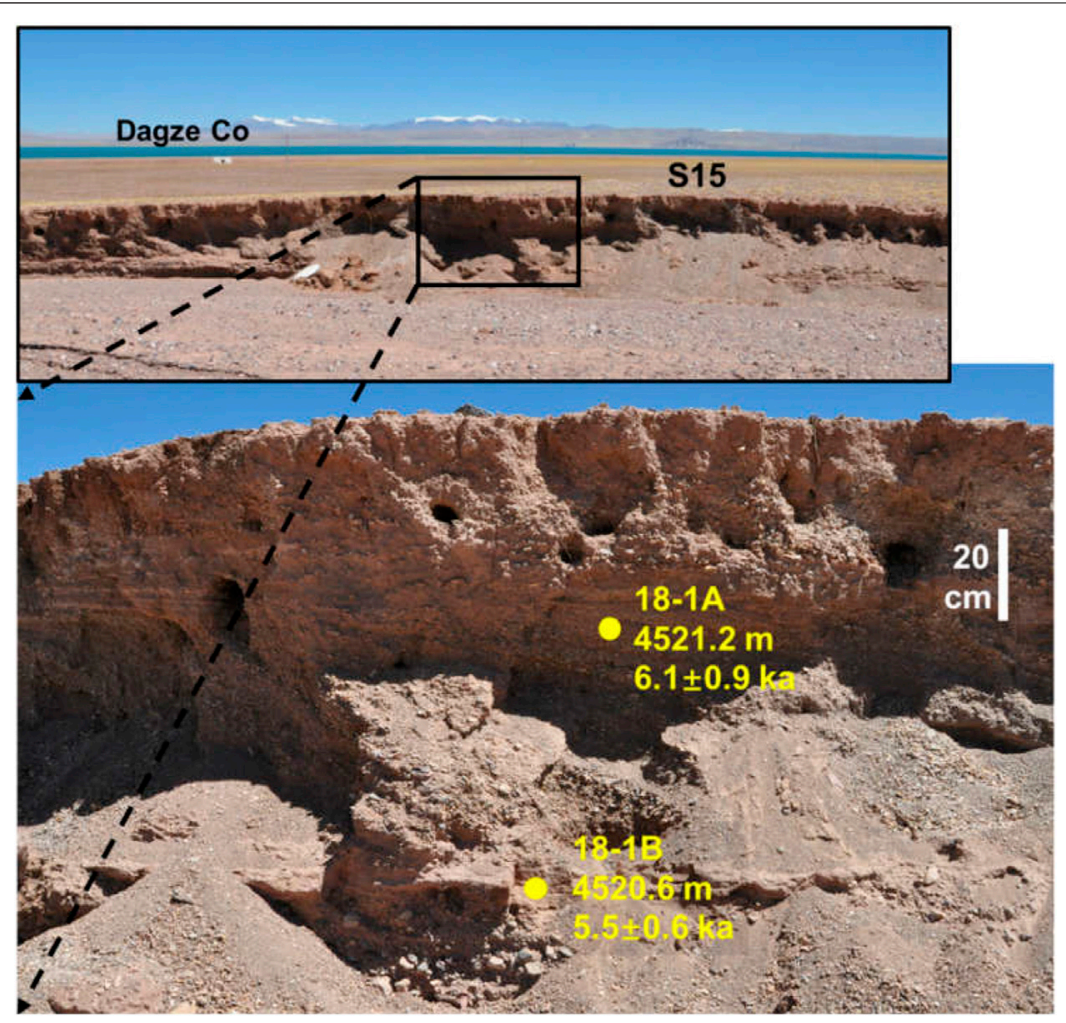

FIGURE 4 | Paleoshoreline S15 and profile 18-1. This shoreline is the highest visible paleoshoreline surrounding the lake and extends from the southern to the eastern lake margin. OSL dating sample 18-1A was collected from the beach gravels where there is a large sand component. OSL dating sample 18-1B was collected from the middle part of the medium sand layer.

are $6.1 \pm 0.9$ and $5.5 \pm 0.6 \mathrm{ka}$, respectively, suggesting Dagze Co reached its highest lake level during the mid-Holocene (Figure 4; Supplementary Figure S8; Table 1). The lake greatly expanded at its highest lake level stage (Figure 1B), with the lake area reaching $\sim 839 \mathrm{~km}^{2}, 2.8$ times its present size. Dagze Co would have overflowed to the west into lower basins when it reached the highest level at S15 as evidenced by a remnant channel connecting Dagze Co with the western basins. The dividing crest between Dagze Co and the western basins is approximately the same elevation as paleoshoreline S15. Hence, water balance ratios in the Dagze Co basin were likely sufficient to sustain the lake at the same elevation of paleoshoreline S15 or slightly higher during the early Holocene ISM intensification stage when several other lakes on southern TP experienced their highest Holocene lake levels (Liu et al., 2016; Shi et al., 2017; Chen et al., 2020).

\section{DISCUSSION}

\section{Asymmetrical Humidity Variations Between the Northern and Southern TP During the LGM}

The Antarctic and Artic ice sheets expanded and mountain glaciers around the world also advanced as the global mean surface air temperature declined by $\sim 4^{\circ} \mathrm{C}$ during the LGM (Clark et al., 2009; Annan and Hargreaves, 2013). The reconstructed surface temperature over the TP and its adjacent regions was $5-8^{\circ} \mathrm{C}$ colder than today during the LGM (Xu et al., 2013; Zhang et al., 2020). Although there are several paleoenvironmental proxy records spanning the LGM in the northern TP (An et al., 2012; Yan and Wünnemann, 2014; Jin et al., 2015; Wu et al., 2020), most studies in the southern TP cover only the last deglacial and Holocene periods, with only a few extending to the latest stage of the LGM (Gasse et al., 1991; Zhu et al., 2015; Ma et al., 2019; Chen et al., 2020 and references cited there in).

During the LGM, the northern TP became colder, drier and windier, and lakes within this region were much reduced or even desiccated (An et al., 2012; Yan and Wünnemann, 2014; Wu et al., 2020). An intensified East Asian Winter Monsoon (EAWM) entered the western Qaidam Basin through several low altitude mountain passes and moved eastward to influence most areas of the northeastern TP, keeping the Asian summer monsoon (ASM) at bay and causing mean annual precipitation to decrease further (Yang et al., 2017). As a result, lakes in the northeastern TP significantly regressed; the water level of Hala Lake was $\sim 50 \mathrm{~m}$ lower than today (Figure 5A, Yan and Wünnemann, 2014), Qinghai Lake almost dried up due to a weakened ASM that caused a decrease in precipitation (Figure 5B, Madsen et al., 2008; Liu et al., 2015; Jin et al., 2015), and Dalianhai Lake was also 
TABLE 1 |Summary of shoreline codes, elevations, aliquot numbers, equivalent doses, age models, water contents, dose rates, ages and selected ages used in the context. Uncertainties of individual quartz ages contain both random and systematic components. "MAM-3" is the abbreviation of the 3-parameter minimum-age model, and "CAM" is the abbreviation of the central-age model (Arnold et al., 2007).

\begin{tabular}{|c|c|c|c|c|c|c|c|c|c|c|}
\hline $\begin{array}{l}\text { Sample } \\
\text { code }\end{array}$ & $\begin{array}{c}\text { Shoreline } \\
\text { num }\end{array}$ & $\begin{array}{c}\text { Sample } \\
\text { ele } \\
\text { (m.a.s.l) }\end{array}$ & $\begin{array}{l}\text { Grain } \\
\text { size } \\
(\mu \mathrm{m})\end{array}$ & $\begin{array}{c}\text { Aliquot } \\
\text { num }\end{array}$ & De (Gy) & $\begin{array}{c}\text { Age } \\
\text { model }\end{array}$ & $\begin{array}{c}\text { Water } \\
\text { content } \\
(\%)\end{array}$ & $\begin{array}{c}\text { Dose } \\
\text { rate } \\
\text { (Gy/ka) }\end{array}$ & Age (ka) & $\begin{array}{c}\text { Age } \\
\text { selected }\end{array}$ \\
\hline \multirow[t]{3}{*}{$17-10-1$} & $\mathrm{~S} 10$ & 4,499.9 & $90-125$ & 50 & $56.9 \pm 2.3$ & CAM & $20 \pm 5$ & $2.32 \pm 0.16$ & $24.5 \pm 1.9$ & \\
\hline & & & & & & & $15 \pm 5$ & $2.47 \pm 0.17$ & $23.0 \pm 1.8$ & $\checkmark$ \\
\hline & & & & & & & $10 \pm 5$ & $2.63 \pm 0.18$ & $21.7 \pm 1.7$ & \\
\hline \multirow[t]{3}{*}{$17-10-2$} & S10 & $4,500.5$ & $38-63$ & 50 & $66.9 \pm 1.0$ & MAM-3 & $20 \pm 5$ & $2.88 \pm 0.19$ & $23.3 \pm 1.6$ & \\
\hline & & & & & & & $15 \pm 5$ & $3.07 \pm 0.21$ & $21.8 \pm 1.5$ & $\checkmark$ \\
\hline & & & & & & & $10 \pm 5$ & $3.26 \pm 0.22$ & $20.5 \pm 1.4$ & \\
\hline \multirow[t]{3}{*}{$17-10-3$} & S10 & $4,500.8$ & 63-90 & 50 & $64.1 \pm 2.0$ & CAM & $20 \pm 5$ & $2.55 \pm 0.19$ & $25.2 \pm 2.0$ & \\
\hline & & & & & & & $15 \pm 5$ & $2.71 \pm 0.20$ & $23.7 \pm 1.9$ & $\checkmark$ \\
\hline & & & & & & & $10 \pm 5$ & $2.87 \pm 0.21$ & $22.3 \pm 1.8$ & \\
\hline \multirow[t]{3}{*}{$17-10-4$} & S10 & $4,501.1$ & $90-125$ & 50 & $59.6 \pm 1.8$ & CAM & $20 \pm 5$ & $2.45 \pm 0.20$ & $24.4 \pm 2.1$ & \\
\hline & & & & & & & $15 \pm 5$ & $2.60 \pm 0.21$ & $22.9 \pm 2.0$ & \\
\hline & & & & & & & $10 \pm 5$ & $2.76 \pm 0.22$ & $21.6 \pm 1.8$ & $\checkmark$ \\
\hline \multirow[t]{3}{*}{$17-10-5$} & S10 & $4,501.5$ & $90-125$ & 50 & $62.5 \pm 2.1$ & CAM & $20 \pm 5$ & $2.49 \pm 0.26$ & $25.1 \pm 2.7$ & \\
\hline & & & & & & & $15 \pm 5$ & $2.64 \pm 0.26$ & $23.7 \pm 2.5$ & \\
\hline & & & & & & & $10 \pm 5$ & $2.80 \pm 0.27$ & $22.3 \pm 2.3$ & $\checkmark$ \\
\hline \multirow[t]{3}{*}{$17-10-6$} & $\mathrm{~S} 10$ & $4,501.8$ & 38-63 & 50 & $76.6 \pm 8.4$ & MAM-3 & $20 \pm 5$ & $2.85 \pm 0.19$ & $26.9 \pm 3.4$ & \\
\hline & & & & & & & $15 \pm 5$ & $3.03 \pm 0.20$ & $25.3 \pm 3.2$ & \\
\hline & & & & & & & $10 \pm 5$ & $3.22 \pm 0.21$ & $23.8 \pm 3.1$ & $\checkmark$ \\
\hline \multirow[t]{3}{*}{$18-1 \mathrm{~A}$} & S15 & $4,521.2$ & $90-125$ & 50 & $15.0 \pm 1.1$ & MAM-3 & $20 \pm 5$ & $2.18 \pm 0.28$ & $6.8 \pm 1.0$ & \\
\hline & & & & & & & $15 \pm 5$ & $2.31 \pm 0.29$ & $6.4 \pm 0.9$ & \\
\hline & & & & & & & $10 \pm 5$ & $2.45 \pm 0.30$ & $6.1 \pm 0.9$ & $\checkmark$ \\
\hline \multirow[t]{3}{*}{ 18-1B } & S15 & 4,520.6 & $90-125$ & 44 & $14.8 \pm 0.6$ & CAM & $20 \pm 5$ & $2.40 \pm 0.24$ & $6.2 \pm 0.7$ & \\
\hline & & & & & & & $15 \pm 5$ & $2.55 \pm 0.25$ & $5.8 \pm 0.6$ & \\
\hline & & & & & & & $10 \pm 5$ & $2.70 \pm 0.26$ & $5.5 \pm 0.6$ & $\checkmark$ \\
\hline
\end{tabular}

substantially reduced during the LGM (Wu et al., 2020). Ice wedge casts widely developed across the northern TP in response to the sharp cooling (Pan and Chen, 1997; Madsen et al., 2008; Liu and Lai, 2013). Loess, which accumulated on the northeastern TP during and prior to the LGM, was largely eroded away by strong winds and expanded glaciers (Liu et al., 2017; E. et al., 2018). In the Qaidam Basin, extensive evaporite deposits in Qarhan saltlake dating to after 25-24 ka resulted from an increasingly arid climate (Chen and Bowler, 1985). These evaporite depositions persisted until the early Holocene when the climate became humid again (Chen and Bowler, 1985). A recent study also suggests the westerly jet stream strengthened significantly during the LGM, the East Asian Summer Monsoon was weaker than during the interglacial, and temperatures and precipitation during the LGM were lower than those during the mid-Holocene in the northern QTP (Li et al., 2020).

Limited paleoenvironmental records from lacustrine sediments and aeolian sands in the southern TP extending to the end of the LGM also indicate a cold and dry climate with the Westerlies prevailed yearly round (Lai et al., 2009; Zhu et al., 2015; Ma et al., 2019). However, the Guliya ice core record from the western TP indicates that while dust concentrations were high during marine isotope stage 4, concentrations were only moderate during the LGM, suggesting the climate was cold and wet (Wu et al., 2004). Moreover, optical dating and cosmological nuclide dating ages of paleoshorelines indicate Seling Co, Dangqiong Co and Nam Co had LGM lake levels higher than present (Figure 5; Li et al., 2009; Kong et al., 2011;
Zhou et al., 2020), consistent with an interpretation of a cold and wet climate. Our optical dating results from Dagze Co also show the lake enlarged during the LGM, with a lake level reaching $\sim 22 \mathrm{~m}$ above the present.

More than a decade ago, Yu et al. (2003) compiled paleolake data and used a global atmospheric general circulation model (GCM) coupled with a land surface process model to explore LGM climatic conditions for the whole China. They suggested a positive net annual precipitation (P-E) was produced by a decrease in evaporation and an increase in precipitation during the LGM, causing lakes in western China to substantially expand. Subsequently, Zheng et al. (2007) utilized a regional climate model (RegCM2) to simulate the climatic conditions in China at 21 and $6 \mathrm{ka}$. Their results indicate that the TP climate was wet-cold during the LGM, but wet-warm at 6 ka. Recently, Li and Morrill (2013) compiled lake level information for the monsoonal and arid regions of Central Asia and compared them with PMIP2 simulated LGM lake level variations. They found that the LGM lake levels were higher than today in some parts of southern and western TP, while lake levels in the eastern and northern TP declined substantially at the same time. Although only a few lake records in the southern TP reflect LGM high lake levels, they are consistent with these climate simulation results.

In summary, it is clear that climate conditions in the northern TP were cold and dry during the LGM, while the climate conditions were cold and wet in some parts of the southern TP. Why the entire TP was predominantly influenced by the 


\section{Age (ka)}

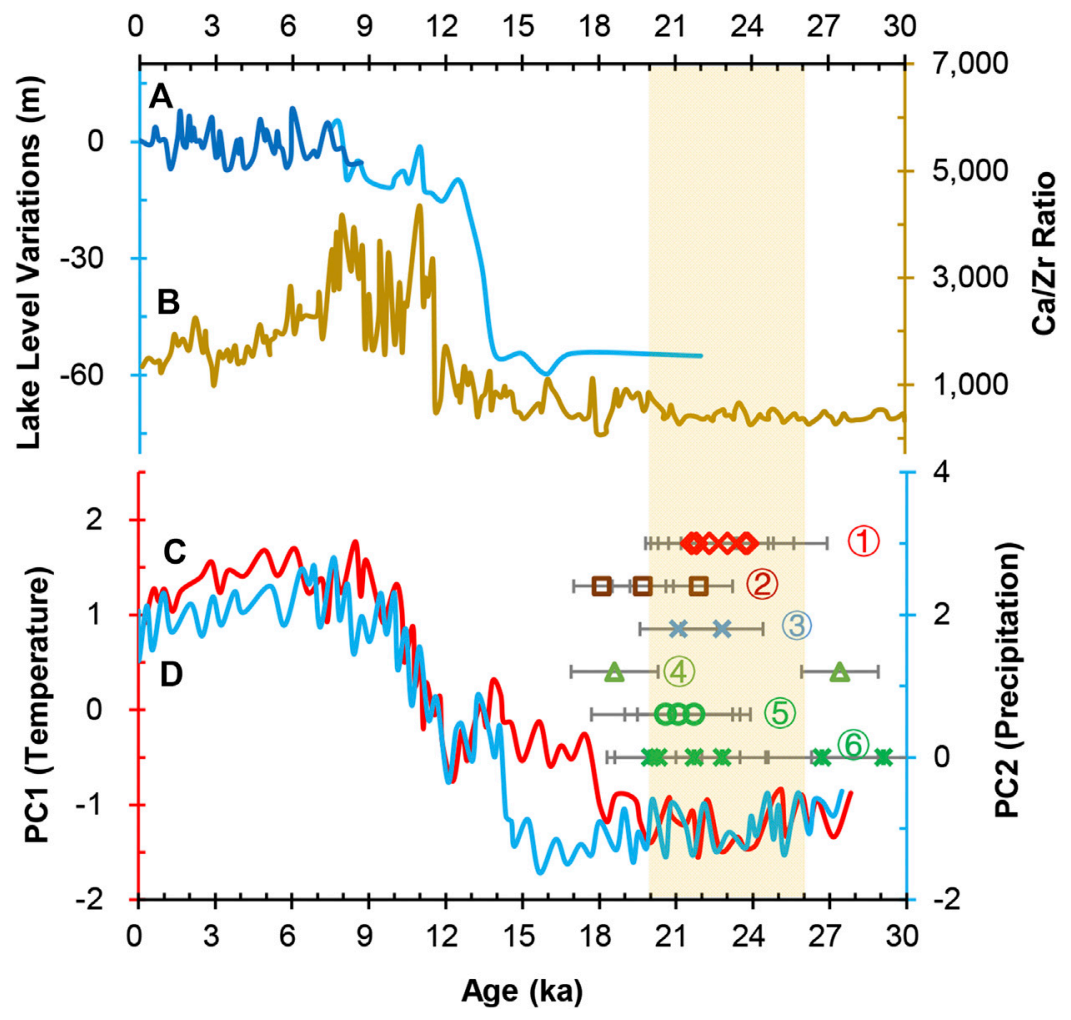

FIGURE 5 | (A) Reconstructed lake level variation curve of Hala Lake (Yan and Wünnemann, 2014). (B) Ca/Zr ratio of lacustrine sediments from Qinghai Lake, representing changes in lake hydrology. Higher values represent more runoff into the lake (Jin et al., 2015). (C) and (D) represent temperature and precipitation changes over Tengchong Qinghai, Yunnan province (Zhang et al., 2020). Precipitation is mainly related to the Indian summer monsoon. The LGM highstand paleoshoreline ages of Dagze Co (this study) (1), Nam Co (Zhou et al., 2020) (2), Dangqiong Co (Kong et al., 2011) (3) and Seling Co (Li et al., 2009) (4). Ages of the travertine layer containing embedded in human fingerprints and footprints at the Quesang archaeological site (Zhang and Li, 2002) (5) and ages of fluvial deposits containing paleolithic stone artifacts at the Nwya Devu archaeological site (Zhang et al., 2018b) (6). The light-yellow band represents the time range of the LGM.

Westerlies during the LGM, but had asymmetrical humidity variations in the northern and southern TP is discussed below.

\section{Asymmetrical Forcing of Net Annual Precipitation during the LGM in the Northern and Southern TP}

During the LGM, ice sheets and sea ice expanded in high latitude areas of the Northern Hemisphere, the annual average temperatures dropped dramatically, the latitudinal temperature gradient between the poles and the equator increased, the Intertropical Convergence Zone migrated southward, midlatitude Westerlies were enhanced, and, most importantly, the ASM significantly weakened (Figure 5D; An et al., 2012; Deplazes et al., 2013). As a consequence, the TP was predominantly influenced by the Westerlies, and monsoonal precipitation markedly decreased (An et al., 2012; Zhu et al., 2015). Surface atmosphere temperatures over the $\mathrm{TP}$ were also $5-8^{\circ} \mathrm{C}$ colder than at present (Figure 5C, Xu et al., 2013; Zhang et al., 2020), and the annual freezing period was prolonged, factors which significantly reduced lake surface evaporation (Li and Morrill, 2013). There was a substantial expansion of glaciers over southern and western $\mathrm{TP}$ in response to this decline in the annual average temperature, but glacier expansion in the central and northern TP was much more limited (Yan et al., 2018; Yan et al., 2020). The expansion of glaciers in the southern TP not only supplied more meltwater to lower elevation lakes during the summer time, but also reduced atmospheric heating over the TP, in turn, weakening the ASM (Liu et al., 2020). The influence of glacial expansion over the TP on LGM climates was explored using the CAM4 climate model (Liu et al., 2020). Simulation results suggest that an expansion of glaciers over the southern and western TP would lead to a decrease in surface air temperatures during both the summer and winter seasons over most regions of the TP (Figures 6A,B). Summer precipitation rates in the western and southern TP would increase slightly, but decrease a little in the eastern and northeastern TP (Figure 6C). Winter precipitation rates would decrease slightly over most of the TP (Figure 6D). This slight increase in summer precipitation, coupled with the decline in summer temperatures and an increase in cold glacier meltwater supply together reduced lake surface evaporation, favoring the appearance of high lake levels in the southern TP. On the other hand, the slight decrease in summer precipitation coupled with the more limited glacier meltwater supply, caused a drier 


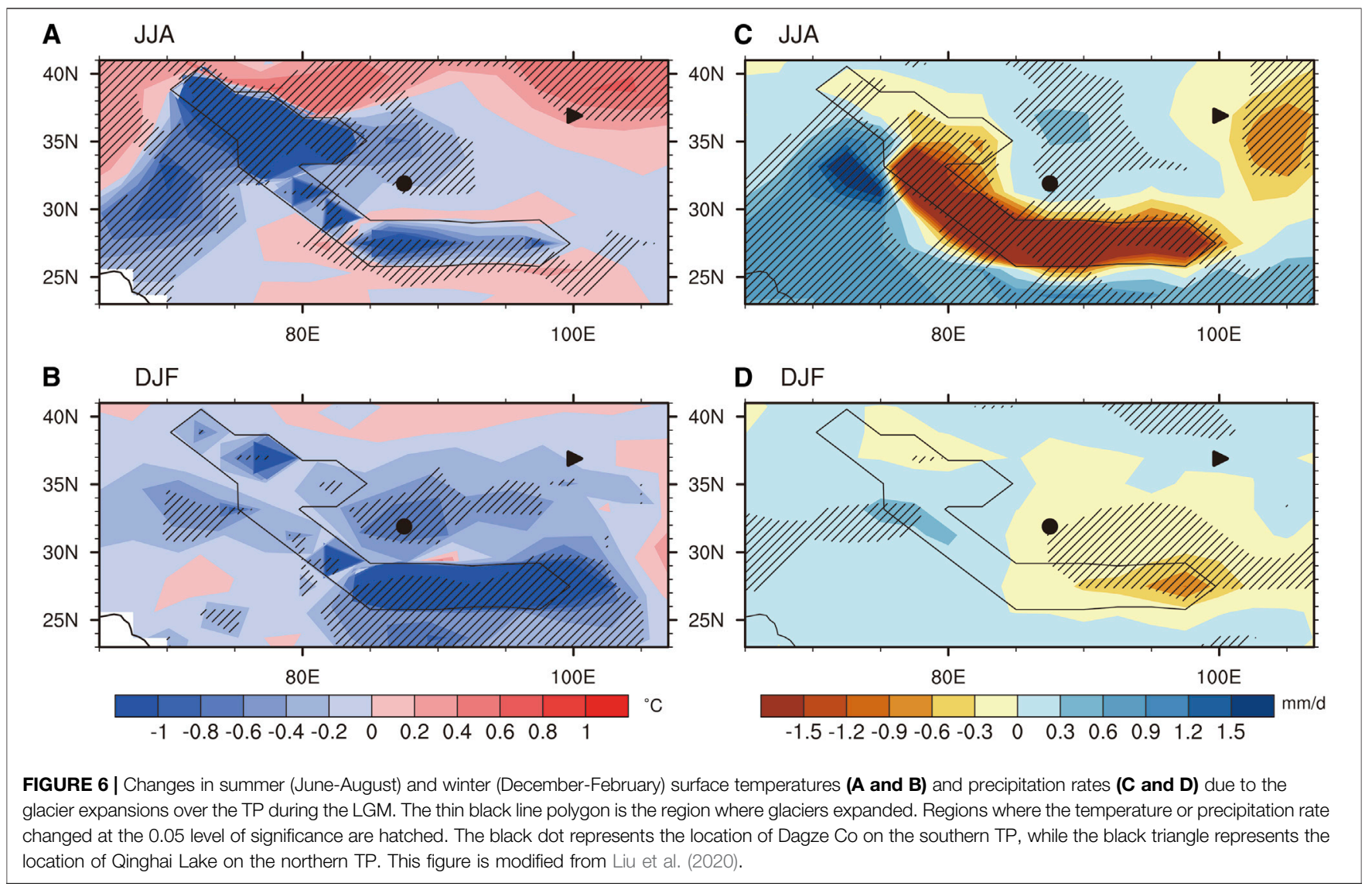

northern TP and a substantial regression of northern TP lakes. We therefore conclude that the differential development and expansion of the glaciers and associated climatic impacts is the major reason for the difference in net annual precipitation between the northern and southern TP during the LGM.

To further explore the spatial precipitation and evaporation changes over the TP during the LGM, we used the TraCE-21 model (Liu et al., 2009) simulation results to obtain annual and seasonal precipitation, net annual precipitation, and annual and seasonal surface atmosphere temperatures over the southern, western and northeastern TP at the LGM, the mid-Holocene $(8-6 \mathrm{ka})$ and the past one thousand years. We selected spatial extents $\left(3.75^{\circ} \times 3.75^{\circ}\right)$ over the southern, western and northeastern TP regions to cover Dagze Co, Longmu Co and Qinghai Lake, respectively. Model results indicate that LGM annual precipitation, net annual precipitation, and seasonal precipitation over the southern TP were similar to the past $1 \mathrm{ka}$. The annual mean temperature was $\sim 4^{\circ} \mathrm{C}$ lower than the past thousand years, while summer and autumn temperatures were $\sim 5.5$ and $\sim 4.5^{\circ} \mathrm{C}$ lower (Tables 2,3 ), respectively. Hence, the increased net water budgets and higher lake levels over the southern TP were caused by enhanced recycling of local moisture, increased summer contributions of glacial meltwater and reduced summer and autumn lake surface evaporation. Summer and autumn precipitation over the northern TP were dramatically reduced during the LGM, and both the annual and summer mean temperatures dropped by $\sim 2$ and $\sim 5^{\circ} \mathrm{C}$ relative to the past 1,000 years (Tables 2, 3), respectively. We therefore speculate that the large amplitude reduction of summer and autumn precipitation are the main reasons the northern TP became more arid compared to the southern TP. Moreover, limited glacial expansion over the northern and northeastern TP resulted in comparatively little meltwater reaching the lakes, adding to the marked LGM lake regressions in the region. Both the mean annual and seasonal precipitation over the western TP increased during the LGM, while the annual and summer mean temperatures dropped by $\sim 4$ and $\sim 7^{\circ} \mathrm{C}$ relative to the past 1,000 years (Tables 2,3 ), respectively. The increased annual precipitation and reduced annual and summer mean temperatures, favored the expansion of regional glaciers, consistent with the interpretation of large-scale glacier advances over the western TP during the LGM (Yan et al., 2018). Because the ASM weakened and it transported limited moisture to the TP during the LGM, the increased annual precipitation in the western TP may be related to the enhanced Westerlies that brought more moisture from the Atlantic Ocean, Europe and Central Asia.

The simulated annual mean surface atmosphere temperatures for northern, southern and western TP during the mid-Holocene were all lower than the past 1,000 years. However, the summer season temperatures for all these regions were higher than the past 1,000 years (Table 3 ), suggesting that the seasonality was 
TABLE 2 | Simulated annual precipitation, net annual precipitation and seasonal precipitation based on the TraCE-21 model. The data were downloaded from webpage http://202.195.239.65:8888/, then reanalyzed.

\begin{tabular}{|c|c|c|c|c|c|c|c|}
\hline \multirow[t]{2}{*}{ Lake name } & \multirow{2}{*}{$\begin{array}{c}\text { Age (ka } \\
\text { BP) }\end{array}$} & \multicolumn{6}{|c|}{ Precipitation (mm/month) } \\
\hline & & Annual & Net annual & Spring (MAM) & Summer (JJA) & Autumn (SON) & Winter (DJF) \\
\hline \multirow[t]{3}{*}{ Dagze Co } & $22-20$ & $46.81 \pm 1.03$ & $20.99 \pm 0.77$ & $41.21 \pm 0.99$ & $35.08 \pm 2.00$ & $65.37 \pm 2.01$ & $45.56 \pm 1.67$ \\
\hline & $8-6$ & $53.85 \pm 1.34$ & $24.81 \pm 1.05$ & $44.18 \pm 1.88$ & $36.50 \pm 2.39$ & $88.17 \pm 3.55$ & $46.57 \pm 1.70$ \\
\hline & $1-0$ & $47.44 \pm 1.43$ & $19.18 \pm 1.17$ & $41.44 \pm 1.37$ & $31.19 \pm 2.67$ & $68.87 \pm 2.89$ & $48.28 \pm 1.56$ \\
\hline \multirow[t]{3}{*}{ Longmu Co } & $22-20$ & $35.86 \pm 0.63$ & $17.90 \pm 0.48$ & $35.69 \pm 0.94$ & $16.53 \pm 1.13$ & $43.61 \pm 1.71$ & $47.61 \pm 1.07$ \\
\hline & 8-6 & $33.27 \pm 0.80$ & $15.81 \pm 0.63$ & $41.87 \pm 1.58$ & $7.18 \pm 0.77$ & $47.26 \pm 2.29$ & $36.79 \pm 1.65$ \\
\hline & $1-0$ & $30.92 \pm 0.60$ & $13.48 \pm 0.51$ & $34.78 \pm 0.92$ & $10.88 \pm 1.01$ & $37.08 \pm 1.59$ & $40.93 \pm 0.95$ \\
\hline \multirow[t]{3}{*}{ Qinghai lake } & $22-20$ & $83.38 \pm 0.85$ & $42.67 \pm 0.74$ & $68.66 \pm 1.35$ & $174.06 \pm 3.30$ & $72.74 \pm 1.72$ & $18.05 \pm 0.70$ \\
\hline & $8-6$ & $107.84 \pm 1.73$ & $73.59 \pm 1.34$ & $64.03 \pm 2.20$ & $244.35 \pm 5.84$ & $101.28 \pm 2.18$ & $21.68 \pm 1.07$ \\
\hline & $1-0$ & $103.24 \pm 2.63$ & $67.58 \pm 2.54$ & $71.66 \pm 1.75$ & $219.29 \pm 6.56$ & $96.21 \pm 3.67$ & $25.79 \pm 0.55$ \\
\hline
\end{tabular}

TABLE 3 |Simulated annual and seasonal surface atmosphere temperatures based on the TraCE-21 model. The data were downloaded from webpage http://202.195.239. $65: 8888 /$, then reanalyzed.

\begin{tabular}{|c|c|c|c|c|c|c|}
\hline \multirow[t]{2}{*}{ Lake name } & \multirow[t]{2}{*}{ Age (ka BP) } & \multicolumn{5}{|c|}{ Surface Atmosphere Temperature $\left({ }^{\circ} \mathrm{C}\right)$} \\
\hline & & Annual & Spring (MAM) & Summer (JJA) & Autumn (SON) & Winter (DJF) \\
\hline \multirow[t]{3}{*}{ Dagze Co } & $22-20$ & $-10.46 \pm 0.09$ & $-14.31 \pm 0.24$ & $3.84 \pm 0.40$ & $-7.07 \pm 0.30$ & $-24.33 \pm 0.28$ \\
\hline & $8-6$ & $-7.43 \pm 0.12$ & $-12.75 \pm 0.16$ & $9.64 \pm 0.37$ & $-3.92 \pm 0.49$ & $-22.70 \pm 0.24$ \\
\hline & $1-0$ & $-5.97 \pm 0.45$ & $-10.28 \pm 0.79$ & $9.43 \pm 0.51$ & $-2.47 \pm 0.29$ & $-20.56 \pm 0.41$ \\
\hline \multirow[t]{3}{*}{ Longmu Co } & $22-20$ & $-7.39 \pm 0.06$ & $-10.72 \pm 0.25$ & $6.62 \pm 0.29$ & $-4.92 \pm 0.30$ & $-20.53 \pm 0.20$ \\
\hline & $8-6$ & $-3.77 \pm 0.16$ & $-8.67 \pm 0.13$ & $14.49 \pm 0.46$ & $-1.42 \pm 0.46$ & $-19.49 \pm 0.36$ \\
\hline & $1-0$ & $-2.84 \pm 0.21$ & $-6.18 \pm 0.54$ & $12.82 \pm 0.19$ & $-0.73 \pm 0.16$ & $-17.26 \pm 0.25$ \\
\hline \multirow[t]{3}{*}{ Qinghai lake } & $22-20$ & $-4.70 \pm 0.13$ & $-2.36 \pm 0.24$ & $5.24 \pm 0.09$ & $-3.76 \pm 0.25$ & $-17.93 \pm 0.33$ \\
\hline & $8-6$ & $-2.45 \pm 0.14$ & $-2.47 \pm 0.13$ & $10.62 \pm 0.22$ & $-1.53 \pm 0.35$ & $-16.45 \pm 0.31$ \\
\hline & $1-0$ & $-1.64 \pm 0.07$ & $-0.64 \pm 0.17$ & $9.11 \pm 0.08$ & $-0.96 \pm 0.14$ & $-14.07 \pm 0.17$ \\
\hline
\end{tabular}

more significant over the TP during the mid-Holocene. MidHolocene summer and autumn precipitation was higher than both the LGM and the past 1,000 years in the northern and southern TP (Table 2), consistent with the highest paleoshoreline age at Dagze Co and the high lake levels recorded at several other lakes (Liu et al., 2016; Shi et al., 2017; Chen et al., 2020). However, the mid-Holocene winter and spring precipitation over the southern and northern TP was similar to the LGM and the past 1,000 years, suggesting that the Holocene high lake levels were caused by an intensified ASM that brought abundant rainfall during the growing season. In contrast, the western TP net annual and summer precipitation decreased substantially (Table 2), suggesting that the moisture of the western $\mathrm{TP}$ was related primarily to the Westerlies.

\section{Implications for Paleolithic People Living on the Southern TP During the LGM}

During the LGM, multiple proxies indicate that the climate of the northern TP was colder, drier and windier, while the southern TP, or at least parts of it, was colder and wetter. The finding of some genetic continuity between initial paleolithic foragers and modern Tibetans is not enough to infer that paleolithic people may have overcome the harsh LGM climate and occupied the high interior plateau regions of the TP as proposed by Zhao et al. (2009) since any exchange of genetic material may have occurred on the lower elevations TP margins. Two archaeological sites in the interior southern TP are dated to be within or spanning the
LGM, providing some support for the inference from genetic research (Quesang and Nwya Devu sites) (Figure 5; Zhang and Li, 2002; Zhang et al., 2018b). Some other Upper Paleolithic archaeological sites on the TP have also been reported to have been occupied within or slightly earlier than LGM, such as Lenghu No. 1 (Brantingham et al., 2007), Xiao Qaidam (Huang et al., 1987) and Seling Co. (Yuan et al., 2007). However, reports of most of these sites only reflect Paleolithic tools from the ground surface, and buried and dated deposits were not identified, making the ages of these sites difficult to determine. More investigations are required to confirm Paleolithic people occupied the TP during climate harsher LGM.

The modern distribution of biotic communities across the TP, and thus the distribution of plant and animal resources on which past Tibetan populations depended, is directly related to a differential monsoon strength which is rapidly reduced from the southeast to northwest across the TP (Madsen et al., 2017; Guedes and Aldenderfer 2019). We here propose that this southeast to northwest difference was magnified during the LGM. While the extreme conditions of the colder, drier and windier LGM climate made it even more difficult than it is now for Upper Paleolithic foragers to live in the interior of the northern TP during the LGM, these hostile conditions also extended into the TP margins of the northeastern TP, such as around Qinghai Lake. Currently there are no known archaeological sites older than $\sim 15 \mathrm{ka}$ above $\sim 3,000 \mathrm{~m}$ on the northeastern TP margins in areas where Holocene and modern 
agro-pastoralist sites are common (e.g., Madsen et al., 2006; Wang et al., 2020). Prehistoric foragers seem to have moved down to the surrounding lower elevational regions during the LGM and only moved up and re-occupied the interior northern $\mathrm{TP}$ again during the deglacial period when the climate started to become warmer and wetter (Madsen et al., 2017). However, Upper Paleolithic foragers may have seasonally occupied the interior regions of the southern TP since the relatively wetter LGM climate may have favored the growth of forage for large herbivores, which in turn provided major subsistence resources for prehistoric hunters that were absent or reduced in the northern TP. Moreover, sparsely distributed hot springs and caves on the southern TP may also have helped foragers overcome the cold weather. These speculations require substantial comprehensive investigations of LGM flora and fauna on the southern TP to be confirmed, but evidence of large mega-fauna, including mammoth and wooly rhinoceros fossils, has been found in lacustrine sediments around several early and middle Pleistocene paleolakes during cold and wet glacial periods (e.g., Zheng et al., 1985; Han et al., 2013). Moreover, recent research suggests archaic hominins may have occupied the TP in the Middle Pleistocene epoch (before $160 \mathrm{ka}$ ) and successfully adapted to high-altitude hypoxic environments long before the regional arrival of modern Homo sapiens (Chen et al., 2019). The questions of when and how people permanently settled the TP is complex and more studies are needed to get a comprehensive understanding of this process.

\section{CONCLUSION}

In this study, we report the dating of exposed highstand lacustrine sediments and beach sediments surrounding Dagze Co, and show that there were high levels of the lake during the LGM and mid-Holocene. The LGM high lake level (22.4 $\mathrm{m}$ ALL) was caused by intensified local moisture recycling, increased glacier meltwater and decreased lake surface evaporation in the context of extensive glacial expansions over the southern and western TP. Holocene highstands differed in that these lake level increases were mainly in response to an intensified ASM during the earlymiddle Holocene. We combined reported high lake level ages within the TP during the LGM with climate model simulation results, and find that LGM climatic conditions on the southern TP were cold and wet, providing an environment suitable for cold-resistant plant growth and the production of forage for herbivores. These large herbivores, in turn, provided food on

\section{REFERENCES}

An, Z. S., Colman, S. M., Zhou, W. J., Li, X. Q., Brown, E. T., Tomithy Jull, A. J., et al. (2012). Interplay between the Westerlies and asian monsoon recorded in lake Qinghai sediments since $32 \mathrm{ka}$. Sci. Rep. 2, 1-7. doi:10.1038/srep00619

Annan, J. D., and Hargreaves, J. C. (2013). A new global reconstruction of temperature changes at the last glacial maximum. Clim. Past 9, 367-376. doi:10.5194/cp-9-367-2013 which Paleolithic foragers could live. However, the northern TP was cold, dry and windy during the LGM, and these harsher climatic conditions made the human occupation of the interior northern TP much more difficult until after the last deglacial stage. Our results are preliminary and speculative, and more studies are needed to provide a more comprehensive understanding the southern TP environmental conditions and ecosystem compositions during the LGM.

\section{DATA AVAILABILITY STATEMENT}

The original contributions presented in the study are included in the article/Supplementary Material, further inquiries can be directed to the corresponding authors.

\section{AUTHOR CONTRIBUTIONS}

XJL designed the research. XJL and LC performed the research. XJL, XZL, and DM analyzed the data. XJL, DM, and XZL wrote the manuscript. YGL performed the CAM4 climate modeling, and JP analyzed the OSL dating results with age models.

\section{FUNDING}

This work was funded by the Strategic Priority Research Program of the Chinese Academy of Sciences "Pan-third pole environmental change and the construction of green Silk Road" (XDA2004010101), the National Natural Science Foundation of China (41671006) and the Second Tibetan Plateau Scientific Expedition and Research Program (2019QZKK0202).

\section{ACKNOWLEDGMENTS}

We thank A. Sun., F. An, X. Yuan, Y. Liu, F. Zhou, and J. Zhou for their help in the field, and T. Chen for help with the OSL dating.

\section{SUPPLEMENTARY MATERIAL}

The Supplementary Material for this article can be found online at: https://www.frontiersin.org/articles/10.3389/feart.2020.606051/ full\#supplementary-material

Arnold, L. J., Bailey, R. M., and Tucker, G. E. (2007). Statistical treatment of fluvial dose distributions from southern Colorado arroyo deposits. Quat. Geochronol. 2, 162-167. doi:10.1016/j.quageo.2006.05.003

Brantingham, P. J., Gao, X., Olsen, J. W., Ma, H., Rhode, D., Zhang, H., et al. (2007). A short chronology for the peopling of the Tibetan Plateau. Dev. Quat. Sci. 9, 129-150. doi:10.1016/S1571-0866(07)09010-0

Chen, F. H., Welker, F., Shen, C. Z., Bailey, S. E., Bergmann, I., Davis, S., et al. (2019). A late middle Pleistocene denisovan mandible from the Tibetan plateau. Nature 569 (7756), 409-412. doi:10.1038/s41586-019-1139-x 
Chen, F. H., Zhang, J. F., Liu, J. B., Cao, X. Y., Hou, J. Z., Zhu, L. P., et al. (2020). Climate change, vegetation history, and landscape responses on the Tibetan Plateau during the Holocene: a comprehensive review. Quat. Sci. Rev. 243, 106444. doi:10.1016/j.quascirev.2020.106444

Chen, K. Z., and Bowler, J. M. (1985). Preliminary study on sedimentary characterisitcs and evolution of palaeoclimate of Qarhan Salt Lake in Qaidam Basin. Sci. China Chem. 28 (11), 1218-1231 [in Chinese, with English summary]. 10.1360/yb1985-28-11-1218

Clark, P. U., Dyke, A. S., Shakun, J. D., Carlson, A. E., Clark, J., Wohlfarth, B., et al. (2009). The last glacial maximum. Science 325, 710-714. doi:10.1126/science.1172873

Deplazes, G., Luckge, A., Peterson, L. C., Timmermann, A., Hamann, Y., Hughen, K. A., et al. (2013). Links between tropical rainfall and North Atlantic climate during the last glacial period. Nat. Geosci. 6, 213-217. doi:10.1038/ngeo1712

Dong, G. H., Li, R., Lu, M., Zhang, D. J., and James, N. (2020). Evolution of human-environmental interactions in China from the late paleolithic to the bronze age. Prog. Phys. Geogr. 44, 233-250. doi:10.1177/0309133319876802

E, C. Y., Sohbati, R., Murray, A. S., Buylaert, J., Liu, X. J., Yang, L., et al. (2018). Hebei loess section in the Anyemaqen Mountains, northeast Tibetan Plateau: a high-resolution luminescence chronology. Boreas 47, 1170-1183. doi:10.1111/ bor. 12321

Gasse, F., Arnold, M., Fontes, J. C., Fort, M., Gibert, E., Huc, A., et al. (1991). A 13000 year climate record from western Tibet. Nature. 353 (6346), 742-745. doi: $10.1038 / 353742 \mathrm{a} 0$

Guedes, J. D. A., and Aldenderfer, M. (2019). The archaeology of the early Tibetan plateau: new research on the initial peopling through the early bronze age. J. Archaeol. Res. 28, 339-392. doi:10.1007/s10814-019-09137-6

Guérin, G., Mercier, N., and Adamiec, G. (2011). Dose-rate conversion factors: update. Ancient TL 29, 5-8.

Han, J. E., Shao, Z. G., Meng, X. G., Zhu, D. G., Yu, J., Chen, Q. G., et al. (2013). Discovery and significance of manmuthus fossil in Gonghe basin, Qinghai province. Geol. Bull. China 32, 730-733 [in Chinese, with English summary]. doi:10.3969/j.issn.1671-2552.2013.05.005

Hou, J. Z., Tian, Q., Liang, J., Wang, M. D., and He, Y. (2017). Climatic implications of hydrologic changes in two lake catchments on the central Tibetan Plateau since the last glacial. J. Paleolimnol. 58, 257-273. doi:10.1007/s10933-017-9976-9

Huang, W. W., Chen, K. Z., and Yuan, B. Y. (1987). "Paleolithics of Xiao Qaidam lake in Qinghai province in China," in Proceedings of the sino-Australian quaternary meeting, Beijing, China: Science Press 168-172.

Jin, Z. D., An, Z. S., Yu, J. M., Li, F. C., and Zhang, F. (2015). Lake Qinghai sediment geochemistry linked to hydroclimate variability since the last glacial. Quat. Sci. Rev. 122, 63-73. doi:10.1016/j.quascirev.2015.05.015

Kong, P., Na, C. G., Brown, R., Fabel, D., Freeman, S., Xiao, W., et al. (2011). Cosmogenic ${ }^{10} \mathrm{Be}$ and ${ }^{26} \mathrm{Al}$ dating of paleolake shorelines in Tibet. J. Asian Earth Sci. 41, 263-273. doi:10.1016/j.jseaes.2011.02.016

Kuhle, M. (1998). Reconstruction of the 2.4 million $\mathrm{km}^{2}$ late Pleistocene ice sheet on the Tibetan Plateau and its impact on the global climate. Quat. Int. 45-46, 71-108. doi:10.1016/S1040-6182(97)00008-6

Lai, Z. P., Kaiser, K., and Brückner, H. (2009). Luminescence-dated aeolian deposits of late Quaternary age in the southern Tibetan Plateau and their implications for landscape history. Quat. Res. 72, 421-430. doi:10.1016/j.yqres. 2009.07.005

Li, D. W., Li, Y. K., Ma, B. Q., Dong, G. H., Wang, L. Q., and Zhao, J. X. (2009). Lake-level fluctuations since the Last Glaciation in Selin Co (lake), Central Tibet, investigated using optically stimulated luminescence dating of beach ridges. Environ. Res. Lett. 4, 045204. doi:10.1088/1748-9326/4/4/045204

Li, Y., and Morrill, C. (2013). Lake levels in Asia at the Last Glacial Maximum as indicators of hydrologic sensitivity to greenhouse gas concentrations. Quat. Sci. Rev. 60, 1-12. doi:10.1016/j.quascirev.2012.10.045

Li, Y., Peng, S. M., Liu, H. B., Zhang, X. Z., Ye, W. T., Han, Q., et al. (2020). Westerly jet stream controlled climate change mode since the last glacial maximum in the northern Qinghai-Tibet Plateau. Earth Planet Sci. Lett. 549, 116529. doi:10.1016/j.epsl.2020.116529

Liu, X. J., Lai, Z., Madsen, D., Li, G., Yu, L., Huang, C., et al. (2018). Late quaternary highstands of Qinghai Lake, Qinghai-Tibetan plateau. Quat. Sci. 35, 1166-1178 [in Chinese, with English summary]. doi:10.11928/j.issn.1001-7410.2018.05.11

Liu, X. J., Lai, Z. P., Madsen, D. B., and Zeng, F. M. (2015). Last deglacial and Holocene lake level variations of Qinghai Lake, north-eastern Qinghai-Tibetan plateau. J. Quat. Sci. 30, 245-257. doi:10.1002/jqs.2777
Liu, X. J., and Lai, Z. P. (2013). Optical dating of sand wedges and ice-wedge casts from Qinghai Lake area on the northeastern Qinghai-Tibetan Plateau and its palaeoenvironmental implications. Boreas 42, 333-341. doi:10.1111/j.1502 3885.2012.00288.x

Liu, X. J., Madsen, D. B., Liu, R. Y., Sun, Y. J., and Wang, Y. X. (2016). Holocene lake level variations of Longmu Co, western Qinghai-Tibetan Plateau. Environ. Earth Sci. 75, 301. doi:10.1007/s12665-015-5188-7

Liu, X. J., Xiao, G. Q., E, C. Y., Li, X. Z., Lai, Z. P., Yu, L. P., et al. (2017). Accumulation and erosion of aeolian sediments in the northeastern QinghaiTibetan Plateau and implications for provenance to the Chinese Loess Plateau. J. Asian Earth Sci. 135, 166-174. doi:10.1016/j.jseaes.2016.12.034

Liu, X. J., Zhang, X. J., Lin, Y. L., Jin, L. Y., and Chen, F. H. (2019). Strengthened Indian summer monsoon brought more rainfall to the western Tibetan Plateau during the early Holocene. Sci. Bull. 64, 1482-1485. doi:10.1016/j.scib.2019.07. 022

Liu, Y. G., Wu, Y. B., Lin, Z. D., Zhang, Y., Zhu, J., and Yi, C. L. (2020). Simulated impact of the Tibetan glacier expansion on the Eurasian climate and glacial surface mass balance during the last glacial. J. Clim. 33, 6491-6509. doi:10.1175/ JCLI-D-19-0763.1

Liu, Z., Otto-Bliesner, B. L., He, F., Brady, E. C., Tomas, R., Clark, P. U., et al. (2009). Transient simulation of last deglaciation with a new mechanism for bølling-allerød warming. Science 325, 310-314. doi:10.1126/science. 1171041

Lu, D. S., Lou, H. Y., Yuan, K., Wang, X. J., Wang, Y. C., and Zhang, C. (2016). Ancestral origins and genetic history of Tibetan highlanders. Am. J. Hum. Genet. 99, 580-594. doi:10.1016/j.ajhg.2016.07.002

Ma, Q. F., Zhu, L. P., Lu, X. M., Wang, J. B., Ju, J. T., Kasper, T., et al. (2019). Late glacial and Holocene vegetation and climate variations at lake Tangra Yumco, central Tibetan plateau. Global Planet. Change 174, 16-25. doi:10.1016/j. gloplacha.2019.01.004

Madsen, D. B., Ma, H. Z., Brantingham, P. J., Gao, X., Rhode, D., Zhang, H. Y., et al. (2006). The late upper paleolithic occupation of the northern Tibetan plateau margin. J. Archaeol. Sci. 33, 1433-1444. doi:10.1016/j.jas.2006.01.017

Madsen, D. B., Ma, H. Z., Rhode, D., Brantingham, P. J., and Forman, S. L. (2008). Age constraints on the late quaternary evolution of Qinghai Lake, Tibetan plateau. Quat. Res. 69, 316-325. doi:10.1016/j.yqres.2007.10.013

Madsen, D. B., Perreault, C., Rhode, D., Sun, Y. J., Yi, M. J., Brunson, K., et al. (2017). Early foraging settlement of the Tibetan Plateau highlands. Archaeol. Res. Asia 11, 15-26. doi:10.1016/j.ara.2017.04.003

McGee, D. (2020). Glacial-interglacial precipitation changes. Annu. Rev. Mar. Sci. 12, 525-557. doi:10.1146/annurev-marine-010419-010859

Meyer, M. C., Aldenderfer, M. S., Wang, Z., Hoffmann, D. L., Dahl, J. A., Degering, D., et al. (2017). Permanent human occupation of the central Tibetan Plateau in the early Holocene. Science 355, 64-67. doi:10.1126/science.aam9231

Murray, A. S., and Wintle, A. G. (2000). Luminescence dating of quartz using an improved single-aliquot regenerative-dose protocol. Radiat. Meas. 32, 57-73. doi:10.1016/S1350-4487(99)00253-X

Pan, B. T., and Chen, F. H. (1997). Permafrost evolution in the northeastern Qinghai-Tibetan Plateau during the last 150000 years. J. Glaciol. Geocryol. 19, 125-132 [in Chinese, with English summary].

Peng, J., Dong, Z. B., Han, F. Q., Long, H., and Liu, X. J. (2013). R package numOSL: numeric routines for optically stimulated luminescence dating. Ancient TL 31, 41-48.

Prescott, J. R., and Hutton, J. T. (1994). Cosmic ray contributions to dose rates for luminescence and ESR dating: large depths and long-term time variations. Radiat. Meas. 23, 497-500. doi:10.1016/1350-4487(94)90086-8

Qiang, M. R., Chen, F. H., Song, L., Liu, X., Li, M., and Wang, Q. (2013). Late quaternary aeolian activity in Gonghe basin, northeastern QinghaiTibetan plateau, China. Quat. Res. 79, 403-412. doi:10.1016/j.yqres. 2013.03.003

Qiang, M. R., Jin, Y., Liu, X., Song, L., Li, H., Li, F., et al. (2016). Late Pleistocene and Holocene aeolian sedimentation in Gonghe basin, northeastern QinghaiTibetan plateau: variability, processes, and climatic implications. Quat. Sci. Rev. 132, 57-73. doi:10.1016/j.quascirev.2015.11.010

Qiao, C., Luo, J. C., Sheng, Y. W., Shen, Z. F., Li, J., and Gao, L. J. (2010). Analysis on lake changes since ancient and modern ages using remote sensing in Dagze Co, Tibetan Plateau. J. Lake Sci. 22, 98-102 [in Chinese, with English summary]. doi:10.18307/2010.0114 
Quade, J., and Broecker, W. S. (2009). Dryland hydrology in a warmer world: lessons from the last glacial period. Eur. Phys. J. Spec. Top. 176, 21-36. doi:10. 1140/epjst/e2009-01146-y

Shi, X. H., Kirby, E., Furlong, K. P., Meng, K., Robinson, R., Lu, H. J., et al. (2017). Rapid and punctuated late Holocene recession of siling Co, central Tibet. Quat. Sci. Rev. 172, 15-31. doi:10.1016/j.quascirev.2017.07.017

Shi, Y. F. (2004). The emergence and abandonment of the ice sheet hypothesis over the Qinghai-Xizang Plateau during the ice age. Quat. Sci. 24, 10-18 [in Chinese, with English summary], doi:10.3321/j.issn:1001-7410.2004.01.002

Stauch, G. (2015). Geomorphological and palaeoclimate dynamics recorded by the formation of aeolian archives on the Tibetan Plateau. Earth Sci. Rev. 150, 393-408. doi:10.1016/j.earscirev.2015.08.009

Thompson, L. G., Yao, T., Davis, M. E., Henderson, K. A., Mosley-Thompson, E., Lin, P. N., et al. (1997). Tropical climate instability: the last glacial cycle from a Qinghai-Tibetan ice core. Science 276, 1821-1825. doi:10.1126/science.276. 5320.1821

Tian, L., Masson-Delmotte, V., Stievenard, M., Yao, T., and Jouzel, J. (2001). Tibetan Plateau summer monsoon northward extent revealed by measurements of water stable isotope. J. Geophys. Res. 106, 28081-28088. doi:10.1029/ 2001JD900186

Wang, J., Xia, H., Yao, J. T., Shen, X. K., Cheng, T., Wang, Q. Q., et al. (2020). Subsistence strategies of prehistoric hunter-gatherers on the Tibetan Plateau during the last deglaciation. Sci. China Earth Sci. 63 (3), 395-404. doi:10.1007/ s11430-019-9519-8

Wu, D., Zhou, A. F., Zhang, J., Chen, J. W., Li, Chen, F. H., et al. (2020). Temperature-induced dry climate in basins in the northeastern Tibetan Plateau during the early to middle Holocene. Quat. Sci. Rev. 237, 106311. doi:10.1016/j.quascirev.2020.106311

Wu, G. J., Yao, T. D., Thompson, L. G., and Li, Z. Q. (2004). Microparticle record in the Guliya ice core and its comparison with polar records since the last interglacial. Chin. Sci. Bull. 49, 607-611. doi:10.1360/03wd0419

Xu, X. K., Hu, G., and Qiao, B. j. (2013). Last glacial maximum climate based on cosmogenic ${ }^{10} \mathrm{Be}$ exposure ages and glacier modeling for the head of Tashkurgan Valley, northwest Tibetan Plateau. Quat. Sci. Rev. 80, 91-101. doi:10.1016/j.quascirev.2013.09.004

Yan, D. D., and Wünnemann, B. (2014). Late Quaternary water depth changes in Hala Lake, northeastern Tibetan Plateau, derived from ostracod assemblages and sediment properties in multiple sediment records. Quat. Sci. Rev. 95, 95-114. doi:10.1016/j.quascirev.2014.04.030

Yan, Q., Owen, L. A., Wang, H. J., and Zhang, Z. S. (2018). Climate constraints on glaciation over high-mountain Asia during the last glacial maximum. Geophys. Res. Lett. 45, 9024-9033. doi:10.1029/2018GL079168

Yan, Q., Owen, L. A., Zhang, Z. S., Jiang, N. X., and Zhang, R. (2020). Deciphering the evolution and forcing mechanisms of glaciation over the HimalayanTibetan orogen during the past 20,000 years. Earth Planet Sci. Lett. 541, 116295. doi:10.1016/j.epsl.2020.116295

Yang, Y., Yang, R., Li, X., Han, W., Zan, J., Fang, X., et al. (2017). Glacialinterglacial climate change on the northeastern Tibetan Plateau over the last 600 kyr. Palaeogeogr. Palaeocl. 476, 181-191. doi:10.1016/j.palaeo.2017.04. 007

Yao, T. D., Masson-Delmotte, V., Gao, J., Yu, W. S., Yang, X. X., Risi, C., et al. (2013). A review of climatic controls on $\delta^{18} \mathrm{O}$ in precipitation over the Tibetan Plateau: observation and simulations. Rev. Geophys. 51, 1-24. doi:10.1002/rog.20023

Yu, G., Xue, B., Liu, J., and Chen, X. (2003). LGM lake records from China and an analysis of climate dynamics using a modelling approach. Global Planet. Change 38, 223-256. doi:10.1016/S0921-8181(02)00257-6
Yuan, B. Y., Huang, W. W., and Zhang, D. (2007). New evidence of human activities in the late Pleistocene in the northern Tibetan Plateau. Sci. Bull. 52, 1567-1571.

Zhang, D. D., and Li, S. H. (2017). Comment on Permanent human occupation of the central Tibetan Plateau in the early Holocene. Science 357, eaam9231. doi:10.1126/science.aam 9231

Zhang, D. D., and Li, S. H. (2002). Optical dating of Tibetan human hand- and footprints: an implication for the palaeoenvironment of the last glaciation of the Tibetan Plateau. Geophys. Res. Lett. 29, 161-163. doi:10.1029/ 2001GL013749

Zhang, D. J., Shen, X. K., Cheng, T., Xia, H., Liu, W., Gao, X., et al. (2020). New advances in the study of prehistoric human activity on the Tibetan Plateau. Chin. Sci. Bull. 475-482 [in Chinese, with English summary]. doi:10.1360/TB2019-0382

Zhang, D. J., Xia, H., and Chen, F. H. (2018a). Early human occupation of the Tibetan Plateau. Sci. Bull. 63, 1598-1600. doi:10.1016/j.scib.2018.12.004

Zhang, X. L., Ha, B. B., Wang, S. J., Chen, Z. J., Ge, J. Y., Long, H., et al. (2018b). The earliest human occupation of the high-altitude Tibetan Plateau 40 thousand to 30 thousand years ago. Science 362, 1049-1051. doi:10.1126/ science.aat 8824

Zhang, D., Zhang, N., Wang, J., Ha, B., Dong, G., and Chen, F. (2017). Comment on Permanent human occupation of the central Tibetan Plateau in the early Holocene. Science 357, eaam8273. doi:10.1126/science.aam8273

Zhang, X., Zheng, Z., Huang, K. Y., Yang, X. Q., and Tian, L. P. (2020). Sensitivity of altitudinal vegetation in southwest China to changes in the Indian summer monsoon during the past 68000 years. Quat. Sci. Rev. 239, 106359. doi:10.1016/ j.quascirev.2020.106359

Zhao, M., Kong, Q. P., Wang, H. W., Peng, M. S., Xie, X. D., Wang, W. Z., et al. (2009). Mitochondrial genome evidence reveals successful Late Paleolithic settlement on the Tibetan Plateau. Proc. Natl. Acad. Sci. U. S. A. 106, 21230-21235. doi:10.1073/pnas.0907844106

Zheng, S. H., Wu, W. Y., Li, Y., and Wang, G. D. (1985). Late cenozoic mammalian faunas of Guide and Gonghe basins, Qinghai province. Vertebr. Palasiat. 23, 89-134 [in Chinese, with English summary].

Zheng, Y. Q., Qian, Z. C., He, H. R., Liu, H. P., Zeng, X. M., and Yu, G. (2007). Simulations of water resource environmental changes in China during the last 20000 years by a regional climate model. Global Planet. Change 55, 284-300. doi:10.1016/j.gloplacha.2006.10.001

Zhou, J., Zhou, W. J., Dong, G. C., Hou, Y. Y., Xian, F., Zhang, L., et al. (2020). Cosmogenic ${ }^{10} \mathrm{Be}$ and ${ }^{26} \mathrm{Al}$ exposure dating of Nam Co lake terraces since MIS 5, southern Tibetan Plateau. Quat. Sci. Rev. 231, 106175. doi:10.1016/j. quascirev.2020.106175

Zhu, L. P., Lu, X. M., Wang, J. B., Peng, P., Kasper, T., Daut, G., et al. (2015). Climate change on the Tibetan Plateau in response to shifting atmospheric circulation since the LGM. Sci. Rep. 5, 13318. doi:10.1038/srep13318

Conflict of Interest: The authors declare that the research was conducted in the absence of any commercial or financial relationships that could be construed as a potential conflict of interest.

Copyright $\odot 2020$ Liu, Cong, Li, Madsen, Wang, Liu and Peng. This is an openaccess article distributed under the terms of the Creative Commons Attribution License (CC BY). The use, distribution or reproduction in other forums is permitted, provided the original author(s) and the copyright owner(s) are credited and that the original publication in this journal is cited, in accordance with accepted academic practice. No use, distribution or reproduction is permitted which does not comply with these terms. 